\title{
Effect of Waiting Time and Process Temperature on the Quality of Commercially Sterilized Flavored Liquid Milk
}

\section{Pengaruh Waktu Tunggu dan Suhu Proses Terhadap Mutu Susu Cair Berperisa Steril Komersial}

\author{
Nur Fitriana Dewi ${ }^{1}$, Eko Hari Purnomo ${ }^{2,3)}$, Purwiyatno Hariyadi ${ }^{2,3)^{*}}$ \\ ${ }^{1)}$ Magister Food Technology, Bogor Agricultural University, Bogor \\ ${ }^{2}$ Department of Food Science and Technology, Bogor Agricultural University, Bogor \\ ${ }^{3}$ Southeast Asian Food and Agricultural Science and Technology Center, Bogor Agricultural University, Bogor

\begin{abstract}
In Indonesia, commercially sterilized flavored liquid milk is regulated requiring minimum $\mathrm{F}_{0^{-}}$ value of 3.0 minutes. Due to batch thermal processing operation, a waiting time, period for product holding before sterilization process at room temperature, is necessary. Waiting time is identified as a critical factor due to potential increase in initial microbial load. Consequently, increase of waiting time might be associated with the need of higher $\mathrm{F}_{0}$-value. The objective of this study was to evaluate the effect of waiting time $\left(0,1,2,3,4,5\right.$, and 6 hours) and process temperatures $\left(121.9,122.6\right.$, and $\left.123.9^{\circ} \mathrm{C}\right)$ for fixed processing time (10 minutes) on the selected quality parameters of commercially sterilized flavored liquid milk. Our result showed no significant increase on the number of microbes, $\mathrm{pH}$, and viscosity of the milk after waiting time up to 6 hours. After sterilization, all products tested with waiting time up to 6 hours and processing temperature at $121.9^{\circ} \mathrm{C}\left(\mathrm{F}_{0}\right.$-value of $11.00-13.54$ minutes), $122.6^{\circ} \mathrm{C}\left(\mathrm{F}_{0}\right.$-value of 15.49-17.01 minutes), $123.9^{\circ} \mathrm{C}$ ( $\mathrm{F}_{0}$-value of $20.53-21.46$ minutes) were organoleptically acceptable. However, decrease of vitamin B1 (6-7, 9.6-10.4, 22-23\%), vitamin C (45-50, 100, and 100\%) were observed at processing temperature of $121.9,122.6$, and $123.9^{\circ} \mathrm{C}$, respectively. These findings shows that the use of processing temperature of $121.9^{\circ} \mathrm{C}$ ( $\mathrm{F}_{0}$-value of 11.00-13.54 minutes) is consider to be the best alternative to produce commercially sterilized flavored liquid milk having waiting time up to 6 hours.
\end{abstract}

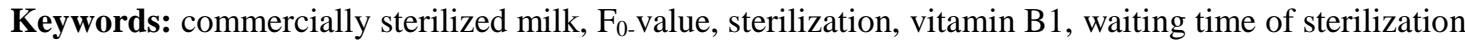

\begin{abstract}
Abstrak. Di Indonesia, susu berperisa steril komersial sebagai produk pangan steril komersial harus memiliki nilai $F_{0}$ minimum 3 menit. Pada proses termal yang dijalankan dengan sistem batch, waktu tunggu sebelum proses sterilisasi tidak dapat dihindarkan. Waktu tunggu didefinisikan sebagai periode waktu produk susu yang menunggu setelah proses pengisian pada botol dan sebelum proses sterilisasi pada suhu ruang. Waktu tunggu menjadi salah satu faktor kritis karena mempengaruhi jumlah mikroba awal. Sebagai akibatnya lama waktu tunggu diduga dapat memengaruhi kebutuhan nilai $F_{0}$ yang lebih tinggi. Penelitian ini dilakukan untuk mengevaluasi pengaruh waktu tunggu ( 0 sampai 6 jam) dan proses sterilisasi dengan suhu sterilisasi yang berbeda $\left(121.9,122.6\right.$, dan $123.9^{\circ} \mathrm{C}$ dengan waktu proses sterilisasi yang tetap (10 menit)) pada mutu susu cair berperisa steril komersial. Hasil penelitian menunjukan bahwa tidak ada perubahan signifikan pada jumlah mikroba, pH, dan viskositas selama waktu tunggu hingga 6 jam. Setelah sterilisasi, seluruh produk susu yang telah mendapatkan perlakuan waktu tunggu dan proses sterilisasi pada suhu $121.9^{\circ} \mathrm{C}$ (nilai $F_{0} 11.00-13.54$ menit), $122.6^{\circ} \mathrm{C}$ (nilai $F_{0}$ 15.49-17.01 menit), $123.9^{\circ} \mathrm{C}$ (nilai $F_{0}$ 20.53-21.46 menit) dapat diterima secara organoleptik. Meskipun demikian terjadi penurunan vitamin B1 (6-7, 10, 22-23\%) dan vitamin C (45-50, 100, dan 100\%) pada suhu proses sterilisasi 121.9, 122.6, dan $123.9^{\circ} \mathrm{C}$ secara berturut-turut. Dari hasil penelitian ini menunjukan bahwa suhu sterilisasi $121.9^{\circ} \mathrm{C}\left(F_{0} 11-13.54\right.$ menit) dan waktu tunggu 6 jam dapat menjadi pilihan yang terbaik dalam proses pembuatan susu cair berperisa steril komersial.
\end{abstract}

Kata Kunci: nilai $F_{0}$, susu steril komersial, sterilisasi, vitamin B1, waktu tunggu sterilisasi

Practical Application: This study provides an information to optimize batch operation for processing of commercially sterilized liquid flavored milk, especially with respect to waiting time. Waiting time is defined as a period of time needed for the product to be ready before the sterilization process at room temperature.

Corresponding: phariyadi@apps.ipb.ac.id 


\section{INTRODUCTION}

For safety reason, low acid foods $(\mathrm{pH}>4.6$ and aw $>0.85$ ), hermetically sealed and stored at room temperature are required to be commercially sterilized. In Indonesia, commercially sterilized food is regulated by Decree of The Head of National Agency of Drug and Food Control of Indonesia number 24, 2016. The regulation required minimum $\mathrm{F}_{0}$-value not less than 3.0 minutes (BPOM 2016). If the D-value for Clostridium botulinum at reference temperature of sterilization of $121.1^{\circ} \mathrm{C}$ is 0.25 minute, thus the minimum requirement of 3.0 minutes for $\mathrm{F}_{0}$-value is equivalent to $12 \mathrm{D}$ process (Hariyadi 2017).

Monitoring and control of good manufacturing practices are needed to ensure that commercial sterility has been achieved to ensure the safety and quality of milk. During in container sterilization process, milk that has gone through preliminary process is filled into bottle for further sterilization. Due to batch thermal processing operation, a waiting time, a period for product holding after filled into bottle and before sterilization process, is necessary. Waiting time, is one of critical factors due to potential increase of initial microbial count. Sunarlim and Widaningrum (2005) reported that storing pasteurized milk at room temperature $\left(27.5^{\circ} \mathrm{C}\right)$ for 6 hours would increase total count bacteria from log $4398 \pm 1793 \mathrm{cfu} / \mathrm{mL}$ up to $\log 5486 \pm 1511 \mathrm{cfu} / \mathrm{mL}$. Due to the possibility of increasing microbial count, increase of waiting time might be associated with the need of higher $\mathrm{F}_{0}$-value. The higher $\mathrm{F}_{0}$-value can be achieved by extending the sterilization time and/or applying higher temperature of processing. However, potential negative impact of higher $\mathrm{F}_{0}$-value should be anticipated; especially with respect to some quality parameters; such as viscosity, specific gravity, $\mathrm{pH}$ and content of vitamin (B1 and C) content of milk due to potential overprocessing (Anandh et al. 2014).

Due to this condition, it is necessary to perform a study to evaluate the effect of waiting time length and sterilization temperatures on the selected quality parameters of commercially sterilized flavored liquid milk product. The quality parameters that will be assessed are organoleptic properties, $\mathrm{pH}$, viscosity, content of vitamin $\mathrm{B} 1$ and $\mathrm{C}$.

\section{MATERIALS AND METHODS}

\section{Material}

This study used a vanilla flavor liquid milk as a model. The liquid milk was filled in a $145 \mathrm{~mL}$ HDPE bottle. Tools used in this study were data logger TMI Orion PicoVACQ, micro pipet, petridish, scot bottle, thermometer, Brookfield Viscometer DV2T, HANNA pHmeter, beker glass, and High Performance Liquid Chromatography (HPLC) Alliance 2695.

\section{Experimental set up}

Before sterilization process, several preliminary processes performed on flavored liquid milk such as homogenization, pasteurization, and filled in a HDPE bottle. The bottled milks were taken as samples after filling process. The initial temperature of milk after bottling was $6-9^{\circ} \mathrm{C}$. Before sterilization, the bottled milk samples were prepared and incubated at a room temperature $29-30^{\circ} \mathrm{C}$ for up to 6 hours. The samples were checked every hour, for product temperature, microbial count (i.e. total mesophilic, total spore, and termophilic), $\mathrm{pH}$, and viscosity. All prepared bottled milks were then sterilized at temperatures of 121.9, 122.6 , and $123.9^{\circ} \mathrm{C}$ for a fixed processing time of 10 minutes. Fixed processing time was applied due to the technical consideration associated with the operation of an industrial scale retort used (STOCK dft technology tipe SRX1300-4-HV-PS-WT, a rotary full water immersion retort, Stock 2017). The quality parameters were analyzed, such as organoleptic parameters, $\mathrm{pH}$, viscosity, content of vitamin $\mathrm{B} 1$ and $\mathrm{C}$. The repetition of analysis also carried out three times.

\section{Calculation of $F_{0}$-value and effect of temperature sterilization process}

The $\mathrm{F}_{0}$-value is calculated based on heat penetration data. The heat penetration was carried out using data logger TMI Orion PicoVACQ. The $F_{0}$-value was calculated by General methods using Microsoft excel by assuming that $\mathrm{z}$ value of $C$. botulinum spore is $10^{\circ} \mathrm{C}$ (Hariyadi 2017).

\section{Temperature of liquid milk}

Temperature of liquid milk was measured using a calibrated digital thermometer. The value is expressed as average of 5 measurements.

\section{Mesophilic microbial count}

Potato count agar was used to determine mesophilic microbe. The plate was incubated at $35 \pm 1^{\circ} \mathrm{C}$ for 48 hours. After the incubation period, the calculated colonies are expressed as cfu/mL (BAM 1998).

\section{Termophilic microbial count}

The thermophilic microbial was determined by using Agate count plate agar. The plates were incubated at $55 \pm 1^{\circ} \mathrm{C}$ for 48 hours. The calculated colonies were recorded as colony forming unit $/ \mathrm{mL}$ (cfu/mL) (BAM 1998).

\section{Total spore microbial count}

Plate Count Agar was prepared to determine total spore microbe. Prior to inoculation, the liquid milk sample was heated at a waterbath at $80^{\circ} \mathrm{C}$ for 10 minutes. Incubation period of total spores was at $35 \pm 1^{\circ} \mathrm{C}$ for 48 hours. Developed colonies were recorded as cfu/mL (BAM 1998). 


\section{pH value}

The value of $\mathrm{pH}$ was determined by using calibrated digital $\mathrm{pH}$ meter (HANNA series HI-2211). $\mathrm{pH}$ meter was calibrated using buffer solution $\mathrm{pH} 4.00$ and 7.00 (Umar et al. 2014).

\section{Viscosity}

Viscosity was measured by using Brookfield Viscometer DV2T, using spindle 1 for viscosity range 1$100 \mathrm{cP}$. The spindle speed rotation was set $60 \mathrm{rpm}$ and milk temperature was set on $25^{\circ} \mathrm{C}$. The values were recorded as centipoises (cP) (Bourne 2002).

\section{Overall organoleptic properties}

Overall organoleptic properties of the commercially sterilized liquid milk were evaluated by the 10 -trained panelists currently employed by the industry. The task of the panelist was simply to determine whether the products were organoleptically acceptable or not, based on overall judgment on color, odor and taste of flavored liquid milk.

\section{Content of vitamin $B 1$ and vitamin $C$}

Measurement of vitamin B1 and vitamin $\mathrm{C}$ were done using HPLC (HP series 1100 with C-18 column and UV-Vis detector (254 nm for vitamin B1 (Lalic et al. 2014) and $245 \mathrm{~nm}$ for vitamin C (Dionex 2016), analyses). Sample injection volume was $100 \mathrm{~mL}$, the mobile phase was buffer methanol (55:45), and flow rate of mobile phase was $0.5 \mathrm{~mL} / \mathrm{min}$ (Lalic et al. 2014).

\section{RESULT AND DISCUSSION}

\section{Effect of waiting time before sterilization to liquid milk quality}

The first stage of this study was to evaluate the effect of waiting time on the increase of initial microbial count, changes in $\mathrm{pH}$, and viscosity of milk. Before sterilization process, several preliminary processes performed on flavored liquid milk such as homogenization, pasteurization and filled in a HDPE bottle. The bottled milk samples were prepared and incubated at a room temperature $29-30^{\circ} \mathrm{C}$ for up to 6 hours. The initial temperature of milk after bottling was $8.96^{\circ} \mathrm{C}$. Along with the increasing waiting time (1, 2, 3, 4, 5, 6 hours), temperature of liquid milk continued to increase, reaching $24.30^{\circ} \mathrm{C}$ after 6 hours of waiting time at room temperature $\left(29-30^{\circ} \mathrm{C}\right)$.

Effect of waiting time and its corresponding increase of temperature on the increase of all types of microbes, i.e mesophilic, total spore and termophilic are shown in Figure 1. Waiting time up to 6 hours is associated with increase of mesophilic (from 0 up to $9.20 \mathrm{cfu} / \mathrm{mL}$,) total spore (from 0 up to $5.00 \mathrm{cfu} / \mathrm{mL}$ ) and thermophilic counts (from 0 up to $3.60 \mathrm{cfu} / \mathrm{mL}$ ). Yuanita et al. (2013) reported that good quality milk contained $4.0 \log \mathrm{cfu} / \mathrm{mL}$ of microbes at most.
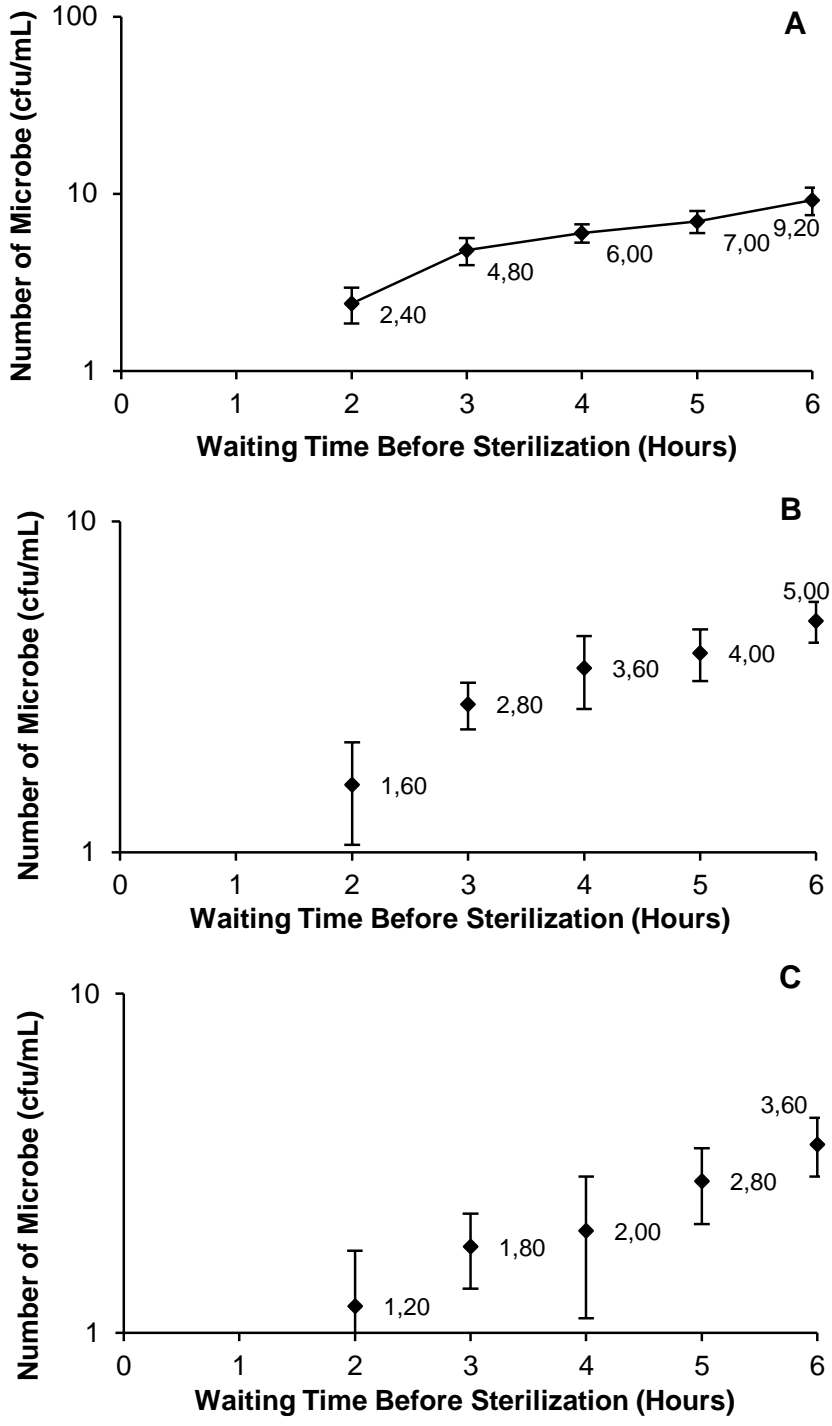

Figure 1. Effect of waiting time on the increase of microbial counts: mesophilic (a) total spore (b) and thermophilic (c)

Furthermore, according to FDA (2011), pasteurized milk (HTST) is considered to have good quality if it contains standard plate count $<20.000 \mathrm{cfu} / \mathrm{mL}$ and coliform $<10 \mathrm{cfu} / \mathrm{mL}$ during storage period. Increase of the microbial loads was less than 1 log and still comply with microbiological limit set by FDA for pasteurized milk (Figure 1).

Elrahman et al. (2013), Nababan et al. (2015), and Cahyaningtyas et al. (2016) reported that microbial activity could be related to changes in physicochemical properties like $\mathrm{pH}$ and viscosity. Figure 2 shows that waiting time up to 6 hours will change the $\mathrm{pH}$ and viscosity of flavored liquid milk but still within the acceptable standard for good quality milk.

Figure 2(a) indicates that $\mathrm{pH}$ of the milk slightly decreased during the waiting time up to 6 hours. $\mathrm{pH}$ of milk product decreased from 7.28 to 6.94. It complied with Indonesian national standard of good quality milk (6-7.5) (BSN 1998). Decreased in milk pH may be influenced by the increasing activity of microorganisms, such as acid producing bacteria which transform sugar (lactose) into lactic acid (Buckle et al. 1987). 
Moreover, Increase in acidity will cause milk casein to coagulate (Ismanto et al. 2013). Microorganism in milk might decreased the quality and damaged the physico-chemical properties of milk, such as odor, texture, appearance, taste, viscosity. Increased in viscosity while waiting time up to 6 hours is shown on Figure 2(b). However, change of viscosity from 6.70 to $7.90 \mathrm{cP}$ was not significant and remain complies with one of dairy industry standard for good quality milk (Memisi et al. 2014).
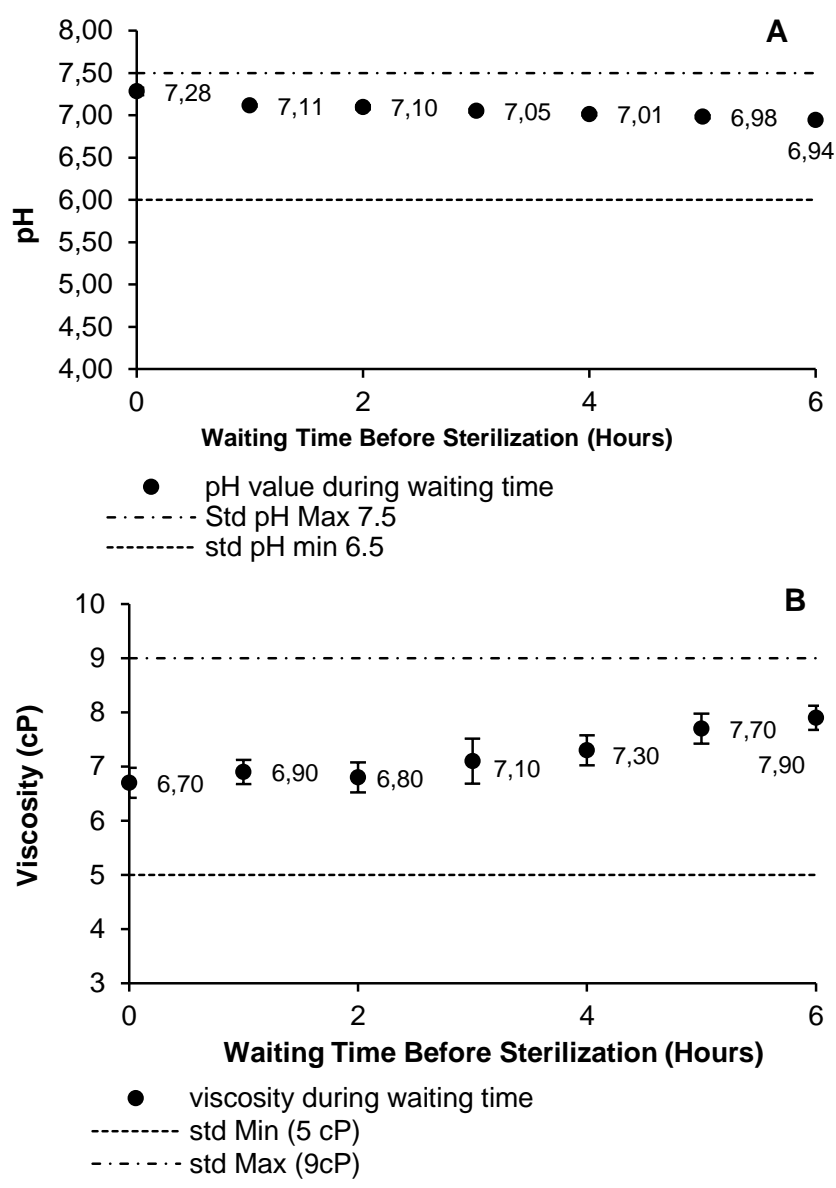

Figure 2. Effect of waiting time on the change of $\mathrm{pH}$ (a) and viscosity (b) of flavored liquid milk

Effect of sterilization process on flavored liquid milk quality

\section{The sterilization process and calculation of $F_{0}$-value}

All liquid milk products treated for waiting time (up to 6 hours) were sterilized at temperature of 121.9, 122.6 , and $123.9^{\circ} \mathrm{C}$. They were evaluated for their quality. Based on the data calculation, various $\mathrm{F}_{0}$-values during sterilization process for 10 minutes at 3 different temperatures were presented in Figure 3 . The $\mathrm{F}_{0}$-value increased as the sterilization temperature increased. For process temperature of $121.9,122.6$, and $123.9^{\circ} \mathrm{C}$, the $\mathrm{F}_{0}$-value measured were 11.00-13.54 minutes, 15.4917.01 minutes, 20.53-21.46 minutes, respectively. As Indonesian regulation, commercially sterilized flavored liquid milk is regulated minimum $\mathrm{F}_{0}$-value of 3.0 minutes, this F0 has met requirement. Along with the high sterilization temperature, change in product quality should be minimized. In general, evaluation of flavored liquid milk quality could be associated with changes in physicochemical properties like color, viscosity, $\mathrm{pH}$, and vitamin (Ling et al. 2015).

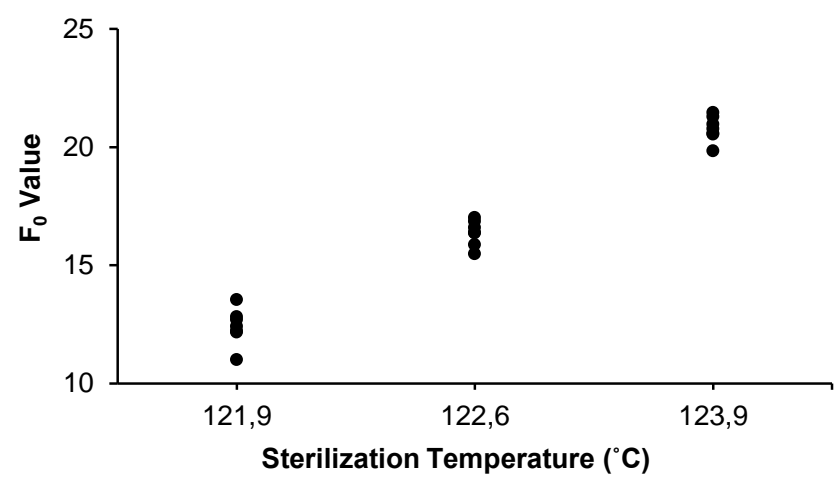

Figure 3. The value of $\mathrm{F}_{0}$-value obtained by commercially sterilized flavored liquid milk during sterilization process for 10 minutes at 3 different temperatures (all products treated for waiting time (up to 6 hours))

\section{Characterization of flavored liquid milk quality with different $\mathbf{F}_{0}$-value}

\section{Organoleptic properties, $p H$ and viscosity of favored liquid milk}

All product tested, products with waiting time up to 6 hours and processing temperature of $121.9^{\circ} \mathrm{C}\left(\mathrm{F}_{0}-\right.$ value of $11.00-13.54$ minutes), $122.6^{\circ} \mathrm{C}\left(\mathrm{F}_{0}\right.$-value of 15.49-17.01 minutes), $123.9^{\circ} \mathrm{C}$ ( $\mathrm{F}_{0}-$ value of $20.53-21.46$ minutes) were organoleptically acceptable by the 10 trained panelists currently employed by the industry.

The value of $\mathrm{pH}$ and viscosity are two of important characteristic of flavored liquid milk. Effect of waiting time up to 6 hours and processing temperature on the change of $\mathrm{pH}$ and viscosity was shown at Figure 4.

Sterilization at different temperature significantly affected the $\mathrm{pH}$ of flavored liquid milk $(\mathrm{P}<0.05)$ (Figure 4(a)). However, for products from the same sterilization temperature, increased of waiting time up to 6 hours have no significant effect on $\mathrm{pH}(\mathrm{P}>0.05)$. At sterilization temperature $121.9^{\circ} \mathrm{C}, \mathrm{pH}$ value was $6.73,122.6^{\circ} \mathrm{C}$ was 6.7 and at $123.9^{\circ} \mathrm{C} \mathrm{pH}$ value was 6.6. Chavan et al. (2011) and Takeda et al. (2015) explained that heating of milk at temperature above $100^{\circ} \mathrm{C}$ causes decrease in $\mathrm{pH}$ due to organic group formation as a result of lactose degradation. Sterilization process with higher $\mathrm{F}_{0}$-value (15-70 minutes) decreased $\mathrm{pH}$ value from 6.6 to 6.2 (Takeda et al. 2015). However, according to the standard of flavored liquid milk, the $\mathrm{pH}$ range obtained (6.0-7.5) is in compliance with the Indonesian national standard.

Effect of waiting time up to 6 hours and processing temperature at different temperatures on the change in viscosity of flavored liquid milk (Figure 4b). Change in viscosity of flavored liquid milk was not significant $(\mathrm{P}>0.05)$ and falls within the range of industry standard of 5-9 cP. In comparison, viscosity of flavored liquid milk after heating is higher than that of milk viscosity 
before heating. This is due to stabilizer which was used for the formulation of flavored liquid milk. The addition stabilizer is aimed to maintain the stability of emulsion, the binding of flavor and water, and to improve the texture, consistency, and stability of liquid in a food product (Tuazon 1996). Moreover, it might extend the shelf life since it is able to prevent the separation of milk fat and milk protein deposition (Sidley 2014).
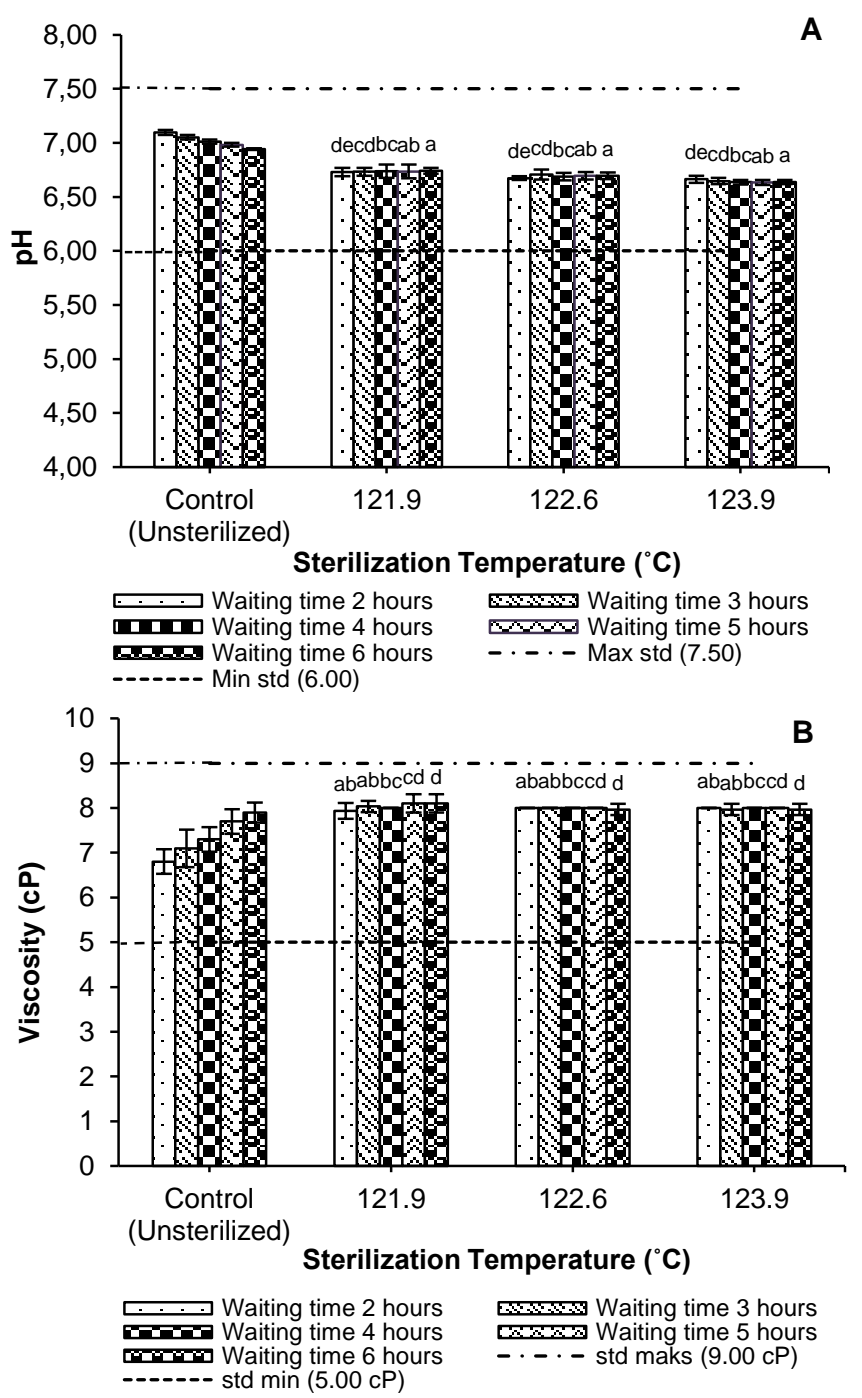

Figure 4. Effect of waiting time up to 6 hours and processing temperature on the change of $\mathrm{pH}(\mathrm{A})$ and viscosity (B) of commercially sterilized flavorred liquid milk

The stabilizer used in this study is based on cellulose and carrageenan. The combination of this stabilizer would be active after heating which was marked by the increasing viscosity. Cellulose was hydrocolloid commonly used in food industry as stabilizer and was able to prevent precipitation of milk casein (Cai et al. 2018). Moreover, carrageenan is polysaccharide made of algae. Pulkkkinen et al. (2014) mentioned that heating would increase in viscosity and product stability.

\section{Vitamin B1 and vitamin C}

The initial amount of Vitamin B 1 and vitamin C were $1.15 \mathrm{mg} / 100 \mathrm{~mL}$ and $0.011 \mathrm{mg} / 100 \mathrm{~mL}$, respectively. After pretreatment and before sterilization process, Vitamin B1 and vitamin C were $1.125 \mathrm{mg} / 100$ $\mathrm{mL}$ and $0.009 \mathrm{mg} / 100 \mathrm{~mL}$. This loss of $2 \%$ and $18 \%$ (respectively) was due to several preliminary processes performed on flavored liquid milk such as homogenization and pasteurization before sterilization.

Asadullah et al. (2010) and Cifelli et al. (2010) mentioned that significant decrease in vitamin B1, B2, B3, B6, B12 and folic acid during heating process depends on the type of milk processing and temperature. Pasteurization process may decrease the nutrients such as folic acid, vitamin B12, vitamin C, B6 and B1 contained in milk, up to $10 \%$. UHT process at temperature of $130-140^{\circ} \mathrm{C}$, there might be a decrease in the level of vitamin B of $10 \%$, folic acid of $15 \%$ (Holdsworth, 1992), and the highest decline in vitamin C of $25 \%$ (Gliguem and Aragon 2005). Lalic et al. (2014) mentioned that UHT process decreases Thiamin level from 0.47 to $0.44 \mathrm{mg} / \mathrm{L}$ and vitamin C loss of $10 \%$ or a decrease from 2.0 to $1.8 \mathrm{mg} / \mathrm{L}$. Some vitamins were sensitive to heat, fat soluble vitamin such as vitamin $\mathrm{A}$ (in the presence of oxygen), D, E, and beta-carotene also water soluble vitamin such as Vitamin C, B1, B2 under acidic condition (Awuah et al. 2007). In general, the highest decrease in the level of vitamin $\mathrm{C}$ in non-acidic food occurs during heating process. In the process of aseptic milk, the degradation of vitamin $\mathrm{C}$ rarely occurred, while lipid, carbohydrate, and other minerals were not affected.

Effects of sterilization process on vitamin $\mathrm{C}$ and vitamin B1 content is presented at Figure 5. The study found that sterilization process at 3 different temperatures condition was significantly correlated with decrease vitamin $\mathrm{B} 1$ and $\mathrm{C}$ level $(\mathrm{P}<0.05)$. Increased of waiting time increased up to 6 hours did not give significant impact $(\mathrm{P}>0.05)$ on content of vitamin $\mathrm{B} 1$. Sterilization temperature at $121.9,122.6$ and $123.9^{\circ} \mathrm{C}$ affected the content of vitamin B1 significantly, with 6$7.5,9.6-10.4$, and $22-23 \%$ reduction from their initial amount, respectively. Effect of sterilization process on vitamin $\mathrm{C}$ content is even more severe. Sterilization temperature of $121.9,122.6$ and $123.9^{\circ} \mathrm{C}$ has caused decrease on vitamin $\mathrm{C}$ content as much as 45-51.3, 100, and $100 \%$, respectively.

\section{CONCLUSION}

This study showed that increased of the number of mesophilic, thermophilic, and total spore and changed the physico-chemical properties ( $\mathrm{pH}$ and viscosity) during the waiting time before sterilization process $(0$ hour up to 6 hours) were not significantly affected the quality of the products to be steriized. All of sterilized products tested, with waiting time of up to 6 hours and processing temperature at $121.9^{\circ} \mathrm{C}\left(\mathrm{F}_{0}\right.$-value of 11.00 13.54 minutes $), \quad 122.6^{\circ} \mathrm{C} \quad\left(\mathrm{F}_{0}\right.$-value of $15.49-17.01$ minutes), $123.9^{\circ} \mathrm{C}$ ( $\mathrm{F}_{0}$-value of $20.53-21.46$ minutes $)$ were organoleptic acceptable. However, decrease of vitamin $\mathrm{B} 1$ (6-7, 9.6-10.4, 22-23\% respectively) and 
vitamin C (45-50, 100, and 100\%) content were observed at processing temperature of 121.9, 122.6, and $123.9^{\circ} \mathrm{C}$, respectively. These findings shows that among the processing temperature studied, temperature of $121.9^{\circ} \mathrm{C}\left(\mathrm{F}_{0}\right.$-value of $11.00-13.54$ minutes) is considered the best alternative to produce commercially sterilized flavored liquid milk having waiting time up to 6 hours.

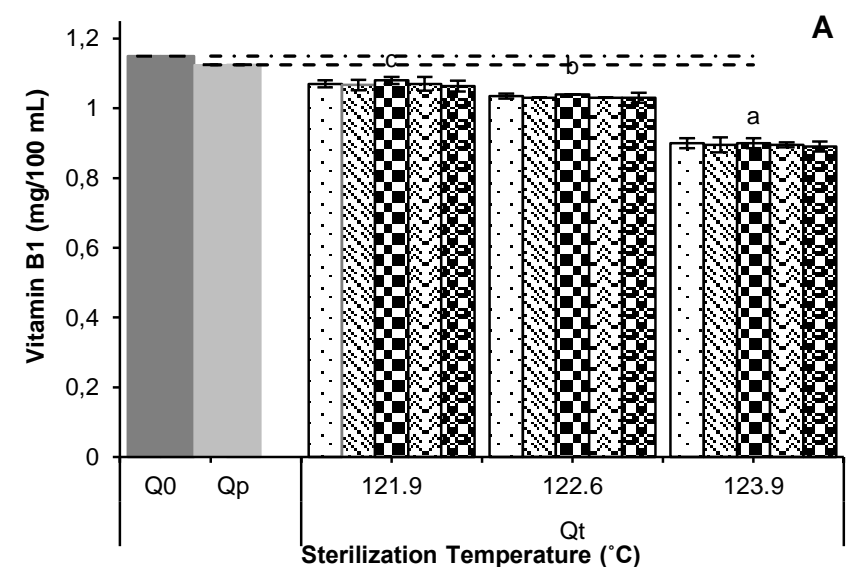

Waiting 2 hours Qt $=$ Vitam Waiting 3 hours Waiting 4 hours Waiting 5 hours 도조요 Waiting 6 hours

- - - - Q0 = the initial amount of Vitamin B1

_. - - Qp = Vit B1 after pretreatment (mixing\&pasteurization)

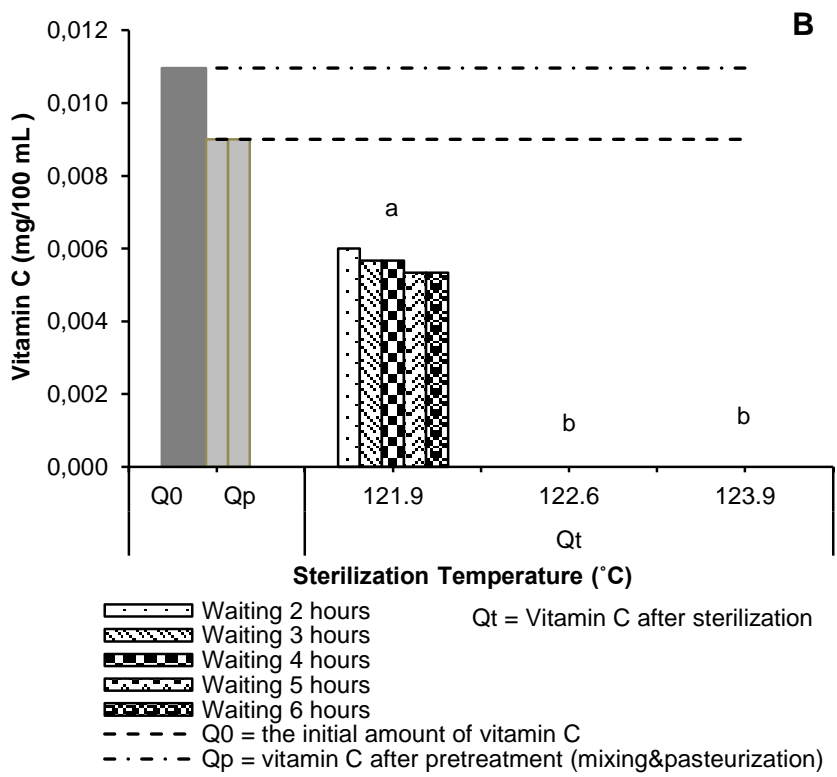

Figure 5. Decrease in vitamin B1 (a) and vitamin C (b) at different sterilization temperature

\section{REFERENCES}

Anandh CP, Ramasamy D, Surendraraj A, Gnanalakkshmi KS. 2014. Process optimazion and self life study of retort processes rose flavoured milk. Int J Food Agr Veterinary Sci 4(1): 36-46.

Asadullah, Nisa K, Omer MT, Syed AA, Khalid J, Begum A. 2010. Study to evaluate the impact of heat treatment on water soluble vitamins in milk. J Pakistan Med Assoc 12: 60-909.
Awuah GB, Ramaswamy HS, Economides A. 2007. Thermal processing and quality: principle and overview. Chem Eng Proces 46: 584-602. DOI: 10.1016/j.cep.2006.08.004.

[BAM] Bacteriologycal Analytical Manual. 1998. Food and Drug Administration, Bureau of Foods, Division of Microbiology, 8th Edition, Published and distributed by AOAC.

Bourne MC. 2002. Food Texture and Viscosity-concept and Measurement, $2^{\text {nd }}$ edition. Academic Press, New York (US). DOI: 10.1016/B978-0121190620/50007-3.

[BPOM] National Agency of Drug and Food Control of Indonesia. 2016. Requirement of commercial sterilized food. http://standarpangan.pom.go.id.

[BSN] National Standardization Agency. 1998. Standard of Fresh Milk Quality. SNI 01-3141-1998.

Buckle KA, Edwards RA, Gleet GH, Wotton M. 1987. Ilmu Pangan. translate: Purnomo HA. Indonesian University-Press, Jakarta.

Cahyaningtyas AA, Pudjiastuti W, Ilham R. 2016. The effects of storage temperature on organoleptic, acidity, and coliform bacteria growth in pasteurized milk. J Riset Teknol Industri 10(1): 13-23. DOI: 10.26578/jrti.v10i1.1732.

Cai Z, Wu J, Du B, Zhang H. 2018. Impact of distribution of carboxymethyl substituents in the stabilizer of carboxymethyl cellulose on the stability of acidified milk drinks. Food Hydrocolloids 76: 150-157. DOI: 10.1016/j.foodhyd.2016.12.034.

Chavan RS, Khedkar CD, Jana AH. 2011. UHT milk processing and effect of plasmic activity on shelf life: Comprehensive Reviews Food Sci Safety 10: 1541-4337. DOI: 10.1111/j.1541-4337.2011.0015 7.x.

Cifelli CJ, Maples IS, Miller GD. 2010. Pasteurizationimplication for food safety and nutrition. Nutr Today 45(5): 207-213. DOI: 10.1097/NT.0b013e31 $81 \mathrm{f} 1 \mathrm{~d} 689$.

Dionex. 2016. Determination of water and fat-soluble vitamins by HPLC. Thermo scientific, Technical Note 89. https://assets.thermofisher.com/TFSAssets/CMD/Application-Notes/88784-TN89-HPL C-WaterFatSolubleVitamins-27Oct2010-LPN2598. pdf. [2 September 2016].

Elrahman SM, Ahmed AM, Zubeir ME, El Owni OA, Ahmed MK. 2013. Effect of storage temperature on the microbiological and physicochemical properties of pasteurized milk. Annals. Food Sci Technol 14(1): 151-121.

[FDA] Food and Drug Administration. 2011. Section 7. Standards for Grade "A" Milk and Milk Products (27-30). Washington DC: United State.

Gliguem H, Aragon IB. 2005. Effect of sterilization, packaging and storage on vitamin $\mathrm{C}$ degradation, protein denaturation, glycation in fortified milks. $\mathrm{J}$ 
Dairy Sci 88(3): 891-899. DOI: 10.3168/jds.S00220302(05)72755-7.

Hariyadi P. 2017. Teknologi Proses Termal Untuk Industri Pangan. Media Pangan Indonesia Bogor.

Holdswort SD. 1992. Aseptic Processing and Packaging of Food Products. Elsivier Science Publishing Co, New York.

Ismanto TS, Utami, Suratim HA. 2013. The influence of storage time in refrigerator on density and viscosity of pasteurized goat milk. J Ilmiah Peternakan 1(1): 69-78.

Lalic J, Denic M, Sunaric S, Kocic G, Trutic N, Mitic S, Jovanovic T. 2014. Assesment of thiamine content in some dairy product and rice milk. CyTA-J Food 12(3): 203-209. DOI: $10.1080 / 19476337.2013 .8$ 14713

Ling B, Tang J, Kong F, Mitcham EJ, Wang S. 2015. Kinetics of food quality changes during thermal processing: a review. Food Bioprocess Technol 8: 343-358. DOI: 10.1007/s11947-014-1398-3.

Memisi NR, Moracanin SM, Skrinjar MM. 2014. Storage temperature: a factor of shelf life of dairy products. Acta Periodical Technol 45: 55-66. DOI: 10.2298/APT1445055M.

Nababan M, Suada K, Swacita I. 2015. The endurance of fresh milk at room temperature storage viewed by alcohol test, degrees acid test and the rate of catalase. Indonesia Med Veterinus 4(4): 374-382.

Pulkkkinen L, Langton M, Gutierrez J. 2014. Storage Stability in a Milk Based UHT-beverage-effect of $\mathrm{pH}$, Carrageenan, and Storage Time [Tesis]. Uppsala, Swedia: Swedish University of Agricultural Science.
Sidley C. 2014. Action mechanism of stabilization of acidified milk drink by CMC. http://cellulose ether.com/action-mechanism-of-stabilization-ofacidified-milk-drinks-by-cmc/. [2 Februari 2018].

Stock. 2017. Operation instruction- Type SRX 1300-4 HV-PS \& micro shuttle. http://www.dft-technology.de/en/products/full-water-immersion.html. [4 November 2017].

Sunarlim R, Widaningrum. 2005. The Way of Heating Temperature and Time Storage on Goat Milk's Shelf Life. Proceeding of National Seminar on Farm and Veterinary Technology. Indonesian Agriculture Postharvest Research, Bogor.

Takeda Y, Shimada M, Ushida Y, Saito H, Iwamoto H, Okawa T. 2015. Effects of sterilization process on the physicochemical and nutritional properties of liquid enteral formula. Food Sci Tehcnol Res 21(4): 573-581. DOI: 10.3136/fstr.21.573.

Tuazon M. 1996. The manufacturing confectioner Presented at the national association of cancy technologies technical session. http://www.gomc. com/firstpage/199611067.pdf. [5 Januari 2018].

Umar, Razali, Novita A. 2014. Derajat keasaman dan angka reduktae susu sapi pasteurisasi dengan lama penyimpanan yang berbeda. J Medika Veterina 8(1): 43-46.

Yuanita PY, Sarwiyono, Surjowardojo P. 2013. Effect of Procedure Before Milking on Milk Quality Based on Reductase Test and California Mastitis Test Fakultas Peternakan [Tesis]. Malang, Brawijaya University.

JMP-04-18-14-Naskah diterima untuk ditelaah pada 16 April 2018. Revis makalah disetujui untuk dipublikasi pada 24 September 2018. Versi Online: http://journal.ipb.ac.id/index.php/jmpi 